American Journal of Agricultural and Biological Sciences 2 (4): 276-283, 2007

ISSN 1557-4989

(C) 2007 Science Publications

\title{
Effect of Fat-Mineral Preparation From Fish Oil on Fatty Acid Content on Cow Milk
}

\author{
${ }^{1}$ Witold Janeczek, ${ }^{2}$ Marek Szoltysik, ${ }^{1}$ Robert Kupczynski, ${ }^{2}$ Józefa Chrzanowska, \\ ${ }^{3}$ Stefania Kinal, ${ }^{1}$ Mariusz Korczynski and ${ }^{1}$ Anna Bartkowiak \\ ${ }^{1}$ Department of Animal Hygiene and Ichthyology, Wroclaw University of Environmental and Life \\ Sciences, Chelmonskiego 38 C, 51-630 Wroclaw, Poland, \\ ${ }^{2}$ Department of Animal Products Technology, Wroclaw University of Environmental and Life \\ Sciences, Norwida 25/27, 50-375 Wroclaw, Poland \\ ${ }^{3}$ Department of Animal Nutrition and Feed Quality, Wroclaw University of Environmental and Life \\ Sciences, Chelmonskiego 38 D, 51-630 Wroclaw, Poland
}

\begin{abstract}
: 8-week-lasting investigation aimed at the assessment of the effect of fish oil application in the form of fat-mineral preparation (F-M) on fatty acid content in milk fat. The subject of this investigation were highly efficient dairy cows (primiparous and multiparous). The cows were administered F-M containing fish oil (1\% in dry mass of ration) which resulted in decreased level of shortchain fatty acids in milk fat and increased level of longchain fatty acids. There was recorded significant increase in isomer cis-9,trans-11 CLA content, as well as the one of polyunsaturated fatty acids of $n-3$ - EPA and DHA group. The number of $n-3$ group acid did considerably increase. The fatty acids $n-6 / n-3$ ratio showed significant decrease in both experimental groups..
\end{abstract}

Key words: dairy cows, fat-mineral preparation, fish oil, fatty acids

\section{INTRODUCTION}

Fodder fat is increasingly often used component of food rations for highly efficient dairy cows. It should be cheap, neutral regarding fermentation in a rumen and, at the same time efficiently used in post-rumen alimentary duct, as well as desirably able to modify fatty acid content of milk fat.

Energy insufficiency, often occurring in the first months of lactation, is supplemented with the addition of tallow ${ }^{[15]}$, vegetable oil of oil plant seeds and waste fats ${ }^{[17,25]}$. There are also applied protected fats - neutral to the rumen environment - lime soaps of fatty acids ${ }^{[7,25,26]}$, seeds of oil plants subjected to a heating or extrusion process ${ }^{[12,26]}$ and prilled fats ${ }^{[16]}$.

The fats of plant origin do significantly differ from the ones of animal origin in the kind of fatty acids they contain ${ }^{[2,6,16]}$. The quantity and kind of fatty acid occurring in animal products are very important for a consumer. A number of fatty acids such as polyunsaturated ones of $n-3$ group of conjugated linoleic acid (CLA) can govern crucial physiological functions in a human organism as their effect is, among the others, anti-atherosclerotic or anticancerogenic ${ }^{[7,22,31,32]}$.

CLA content in milk fat is determined by such factors as, e.g. breed, age, stage of lactation. Yet the strongest effects belongs to food factors ${ }^{[1,7,8,21,23,27,36]}$. Supplementation of food rations for cows with monoand poly- unsaturated fatty acids in the form of seeds, extruded crushed meal, calcium oils and salts influences PUFA biohydrogenation in rumen content, modifying milk composition ${ }^{[2,3,9,26]}$. Linoleic and linolenic fatty acids supplied with forage undergo biohydrogenation in rumen due to Butyrivibrio fibrisolvents and other bacterias to stearic acid. In those alterations cis-9,trans$11 \mathrm{CLA}$ isomer and vaccenic acid (VA, trans- $11 \mathrm{C}_{18: 1}$ ) are intermediate products ${ }^{[6,7]}$. Cis-9,trans-11 CLA present in milk fat is synthesized in $64-78 \%$ in milk gland with VA by $?^{9}$-desaturase (stearoyl-CoA desaturase) ${ }^{[6,10,11,17,27]}$. Cis-9, trans-11 CLA synthesis in milk gland can range up to $91 \%$ of total CLA milk fat content ${ }^{[19]}$. Piperova et al. ${ }^{[28]}$ proved that even $93 \%$ CLA content in milk can be synthesized in mammary gland.

Vegetable oils and extruded crushed meal introduced to cow food resulted in CLA increase in milk fat ${ }^{[1,9,12,20,36]}$. However, more effective, as far as composition and concentration modification of fatty acids including CLA are considered, proved to be application of fish oils ${ }^{[9,14,26]}$ or fish oil with vegetable oils rich in linoleic acid $\mathrm{G}_{8: 2} \mathrm{n}-6^{[2,35]}$. That kind of modification of cow diet effects on the increase in trans-1 $1 \mathrm{G}_{8: 1}$ content ${ }^{[24,33,34]}$, as well as on higher

Corresponding Author: Department of Animal Hygiene and Ichthyology, Wroclaw University of Environmental and Life Sciences, Chelmonskiego 38 C, 51-630 Wroclaw, Poland, Fax: 0048713205866 
endogenic synthesis of cis-9,trans-11 CLA in mammary gland ${ }^{[2]}$.

Taking into account the fact that milk fat enrichment in cis-9,trans-11 CLA, vaccenic acid and omega-3 acid group prove health-promoting factors in human diet, it seems to be justified to carry on investigation regarding the use of different kinds of fat able to desirably modify milk fat content.

The aim of the investigation was the assessment of the effects of fish oil application in the form of fatmineral preparation $(\mathrm{F}-\mathrm{M})$ regarding fatty acids in milk fat in highly efficient dairy cows food.

\section{MATERIALS AND METHODS}

The investigation was conducted on dairy cows farm numbering 250 animals, crossbreeds $\mathrm{cb} \times \mathrm{hf}$ of more than $75 \%$ of hf breed genes, featuring milk yield for previous lactation $8500 \mathrm{~kg}$. The cows were kept in loose barn and fed according to TMR system (total mixed rations). The fodders used for cow feeding (TMR components) were subjected to chemical analysis in Blattin Laboratory in Langenfeld to determine the content of dry mass, total protein, raw ash, raw fat, raw fiber and its fractions (ADF and NDF), as well as mineral components: calcium, phosphorus, magnesium and sodium (4). On the basis of the analysis done, there were worked out food rations for cows according to DLG norms [13]. Quantitative composition and food value of the doses were shown in Table 1.

40 clinically healthy cows were selected for strict examination and, following the analog method, considering the sequence of lactation (primiparous and multiparous in 2 or 3 lactation, as well as milk yield for previous lactation), they were at random classified into 4 equipotent groups. The factor differentiating particular groups was fat-mineral preparation (F-M), additionally administered for 8 weeks twice a day in the dose of $563 \mathrm{~g}$ per head - fish oil amounted $1 \%$ of dry mass ration. The layout for this experiment was shown in Table 2.

F-M preparation contained fish oil $22 \%$, bentonite $33 \%$, vermiculite $33 \%$ and humokarbowite $12 \%$. FM food value was determined according to the methods enforced ${ }^{[4]}$. Fatty acids composition in fish oil (herringsprat) was examined using chromatographic method ${ }^{[30]}$ - gas chromatograph coupled with mass spectrophotometer (GC/MS-mass spectrophotometer by Varian, Saturn 200).

Purified and neutralized extracts were subjected to analysis according to GC/MS technology with the se of capillary column Rt x MS of 30 m length. Fatty acid composition in fish oil was shown in Table 3.
Milk for examinations was collected before the experiments started and after 4 and 8 week of FM administration. Fatty acid composition was determined in representative samples following gas chromatography method (43) with the use of gas chromatograph Agilent Technologies 5973. Separation was carried out in the following conditions: column $60 \mathrm{~m} \times 0.25 \mu \mathrm{m}$, column temperature ranged $140{ }^{\circ} \mathrm{C}(5$ min) to $240{ }^{\circ} \mathrm{C}\left(4{ }^{\circ} \mathrm{C} / \mathrm{min}\right)$, carrier gas - helium $(20$ $\mathrm{m} / \mathrm{s}$ ), spray $1 \mu \mathrm{l}, 260{ }^{\circ} \mathrm{C}$, split 100:1. Considering fatty acids representing product and substrate for ? ${ }^{9}$ desaturase, CLA -desaturase index was calculated ${ }^{[21]}$ :

CLA-desaturase index

$=\frac{\text { cis }-9, \text { trans }-11 C L A}{\text { cis }-9, \text { trans }-11 C L A+\text { trans }-11,18: 1}$

The values obtained were statistically worked out using statistical program Statgraphics ver. 5.0 and difference significance was estimated according to Duncan test.

\section{RESULTS}

The assessment of fatty acid contents in fish oil (Tab. 3) showed that it features high percentage of polyunsaturated fatty acids (PUFA) $-40.43 \%$ including linoleic acid (LA) 7.28\%, a-linolenic acid (ALNA) $3.84 \%$, eicosapentaenoic (EPA) $8.19 \%$ and docoshexaenoic acids (DHA) $13.83 \%$. The sum of $n-6$ acids amounted $10.83 \%$ and those of $n-3$ group -29.3 $\%$. Fish oil contained $26.22 \%$ saturated acids (SFA) including $15.69 \%$ which belonged to palmitic acid $\left(\mathrm{C}_{16: 0}\right)$, while monounsaturated acid content (MUFA) ranged $35.39 \%$, with $22.86 \%$ of oleinic acid $\left(C_{18: 1} n-9 c\right)$ as the highest contribution to the latter group. Bakula et al. ${ }^{[5]}$ showed the similar content of fatty acids in fish fat in theirs investigations.

The cows were administered fat-mineral preparation containing fish oil, which resulted, in the fourth week of its administration, in decreased level of short-chain fatty acid in cow milk fat, both in primiparous and multiparous $\left(\mathrm{C}_{4: 0}-\mathrm{C}_{12: 0}\right)$ while the level of long-chain fatty acids $\mathrm{C}_{16: 1}-\mathrm{C}_{22: 6}$ ) was elevated. Such an evident effect was not observed for the content of medium chain fatty acids (Table 4 and 5). Introduction of polyunsaturated fatty acids to cow feeding is connected with the decrease in synthesis of short- and medium chain fatty acids, especially at 
increased supply of linoleic acid ${ }^{[2,3]}$. Similar effect was recorded in our own experiments, where LA and longchain fatty acids supply was high in the preparation used.

F-M preparation administered primiparous and multiparous cows increased contribution of unsaturated fatty acids in cow milk fat and the content of saturated fatty acid decreased. This growth was observed as early as fourth week of F-M administration (Tab. 4 and 5).

In the case of control cows, primiparous and multiparous, in the period of 8-week-experiment milk fat showed slight differences in trans-11 $\mathrm{G}_{8: 1}$ isomer content. In milk fat of the cows receiving F-M preparation the content of vaccenic acid amounted 0,98 $\mathrm{g}$ for heifers (group II) and 1,45 g per $100 \mathrm{~g}$ milk fat for multiparous (group IV) on the day the experiment begun. After 8-week-preparation administration the quantity if that acid increased to 3,8 and $3,71 \mathrm{~g}$ per 100 $\mathrm{g}$ fatty acids $(\mathrm{p}=0.01)$ in II and IV group respectively.

On the day the investigation started the content of cis-9,trans-11 isomer in cow milk fat showed similar level in particular groups $0.54 \mathrm{~g}$ (group I and III) and $0.64 \mathrm{~g}$ (group II and IV) per $100 \mathrm{~g}$ fatty acids. Significant increase in cis -9,trans-11 CLA was recorded in cow milk fat as early as 4 weeks of administration F$\mathrm{M}$ preparation $(\mathrm{p}=0.01)$, while after 8 weeks cis-9, trans-11 CLA content amounted 1.97 (heifers group II) and $2.82 \mathrm{~g} / 100 \mathrm{~g}$ fatty acids (multiparous group IV Fig. 1). The increase was also observed in the case of CLA/unsaturated fats ratio in cow milk from both experimental groups. The value of desaturase CLA index did considerably increase in multiparous (group IV) administered F-M preparation, while in primiparous such a dependence was not recorded.

Fish oil introduction into cow diet resulted in higher values polyunsaturated fatty acids of n-3 group-EPA and DHA in primiparous and multiparous cows milk fat. EPA content increased from $0,03 \mathrm{~g}$ to $0,4 \mathrm{~g}$ (primiparous) and from $0,02 \mathrm{~g}$ to $0,56 \mathrm{~g}$ (multiparus) per $100 \mathrm{~g}$ fatty acids. In milk fat of control group DHA content was below its detectable point. F-M preparation administered to cows for 8 weeks cost the increase in DHA content $(p=0.01)$ in milk fat collected from the cows of group II and IV to $0,18 \mathrm{~g}$ and $0,31 \mathrm{~g} / 100 \mathrm{~g}$ fatty acids respectively. The sum of $n-3$ group fatty acids did significantly increase, especially in multiparous and n-6/n-3 fatty acids ratio on the day the experiments begun was lower in primiparous than in multiparous. It underwent lowering after 4 weeks of F$M$ preparation administration in primiparous and multiparous and in latter ones it reached the highest values (Table 5).

\section{DISCUSSION}

In the recent years there were many investigations regarding food alteration possibilities of fatty acids content modification in cow milk fat. Food ration supplementation with oil plant seeds, directly with oils or their calcium salts effects on PUFAs biohydrogenation in rumen content modifying milk composition ${ }^{[2,3,9,12,23]}$. Linoleic acid and linolenic acid, as well as oleic one are precursors for cis-9, trans-11 CLA synthesis, vaccenic acid and other trans $\mathrm{C}_{18: 1}$ and CLA isomers in the course of biohydrogenation process in rumen ${ }^{[6]}$. The acids trans-7, trans-11 and trans-11 18:1 are substrates for endogenic synthesis of trans7,cis-9, cis-9,trans-11 CLA and cis-9,trans-12 18:2 by 9-stearoyl-CoA desaturase [11,17,28], although the occurrence of trans-18:1 trans-18:2 and CLA isomers in milk reflects, to a high degree, the stages of fatty acids $\mathrm{C}: 18$ biohydrogenation in rumen.

Apart from vegetable oils, still increasing number of investigations involve supplementation of cow food rations with animal fats, especially fish oils $[1,2,3,14,34,35,36]$. Application of fish oil as supplementation to cow food rations caused higher increase of cis-9, trans-11 CLA content in milk than the use of vegetable oils ${ }^{[9]}$, although considerable increase in CLA quantity was also recorded after introduction of sunflower oil, i.e. CLA content ranged $2.44 \mathrm{~g} / 100 \mathrm{~g}$ fatty acids ${ }^{[20]}$.

CLA content in cow milk can result from individual differences in rumen flow TVA, as well as from ? desaturase activity in a milk ${ }^{\text {[7] }}$ gland and effects the value of CLA desaturase index. Cis-9,trans-11 isomer provides for about $75-90 \%$ total CLA of milk fat ${ }^{[6,7,11]}$. Endogenic synthesis is of a basic meaning for cis-9, trans-11 CLA content in milk fat. Shingfield et al. ${ }^{\text {[33] }}$ showed significantly increased duodenal flow of trans$11 \mathrm{G}_{8: 1}$ isomer in rumen content after the cows had been administered $250 \mathrm{~g}$ of fish oil daily (17.1 $\mathrm{g}$ and $121.1 \mathrm{~g}$ daily control and fish oil respectively). Polyunsaturated fatty acids EPA and DHA contained in fish oil inhibit trans-C18:1 reduction to 18:0 during hydration of fatty acids present in basic cow diet and lead to cumulation of trans-10 C18:1 in rumen content 
[24]. Application of fish oil also effects on the number of protozoa in rumen content ${ }^{[24]}$.

In Poland the fish oils are obtained mainly from herrings, sprats an mackerels. American investigation involving cow food made use of fish oil originating from menhadan. That oil contained less EPA and DHA -10.93 and $11.92 \mathrm{~g} / 100 \mathrm{~g}$ fatty acids respectively than fish oil applied in our own investigation ${ }^{[2,3]}$, while the content of polyunsaturated fatty acids was lower than the one in our own investigation.

The research carried out by Donovan et al, involving the effect of different fish oil doses on milk efficiency and composition proved that application of fish oil to cow food caused significant increase in cis11, trans-12, CLA, vaccenic acid and n-3 group acids in milk fat. The most effective was $2 \%$ of fish oil addition that it caused cis-9, trans-12 CLA and vaccenic acid increase by $360 \%$ and $430 \%$, respectively ${ }^{[14]}$. In our own investigation, in spite of supplementing food ration with $1 \%$ of fish oil, the increase in cis-9, trans-11 CLA ranged $364.8 \%$ and $454.8 \%$ for primiparous and multiparous, respectively (Tab. 4 and 5).

Considering concentration of linoleic and linolenic acid, the use of fish and vegetable oils combination containing high amounts of those acids proved to be satisfactorily effective ${ }^{[2,3,36]}$. Abu-Gazaleh et al. [3] obtained increased cis-9, trans-11 CLA concentration using combined doses $0.5 \%$ of fish oil and $2 \%$ of dry mass food ration of soy oil (from extruded soybeans). More effective was using of fish oil combined with increased amount of linoleic acid (from sunflowers). After 4 weeks supplementation of $1 \%$ of fish oil with the addition of sunflower oil (high quantity of LA), cis9, trans-11 CLA and vaccenic acid concentration in milk fat ranged $1.7 \mathrm{~g}$ and $3.79 \mathrm{~g} / 100 \mathrm{~g}$ fatty acids, respectively ${ }^{[2]}$. Shingfield et al. [34] reported that administration of fish oil with sunflower oil resulted (on the fifth day) in higher cis-9, trans-11 CLA concentration up to $5.37 \mathrm{~g} / 100 \mathrm{~g}$ fatty acids, while after 15 days of using the mentioned supplementation, concentration of cis-9, trans-11 CLA decreased to $2.35 \mathrm{~g} / 100 \mathrm{~g}$ fatty acids. Similar results were obtained by Whitlock et al [36] who applied combined supplementation of fish oil and extruded soy crushed meal.

In our own investigation the significant increase in cis-9, trans-11 CLA concentration in cow milk fat was showed as early as after 4 weeks of using F-M preparation. CLA/TVA ratio in milk also showed higher value, especially in multiparous. In this period of investigation the growth of cis-9, trans-11 CLA isomer concentration in multiparous milk fat from $0.62 \mathrm{~g}$ to $2.75 \mathrm{~g} / 100 \mathrm{~g}$ fatty acids was observed. Those data resulted from TVA increase in milk fat, i.e. $284 \%$ which caused the increased in endogenic synthesis of CLA in milk gland by stearoyl-CoA desaturase. Investigation by other authors also confirm considerable role of that enzyme in endogenic synthesis of CLA ${ }^{[1,2,6]}$. Our own investigation data showed increased values of CLA isomer up to $2.82 \mathrm{~g} / 100 \mathrm{~g}$ fatty acids after \&-week-administration of F-M preparation. Other authors ${ }^{[1,2,3,14,35]}$, using fish oil or fish oil combined with vegetable oils did not obtain such high CLA increase in milk fat.

Some authors particularly show that in FMR cow feeding system CLA value in milk remains lower in comparison to the milk collected from the cows fed on a pasture ${ }^{[19,21]}$. Therefore, our own investigation confirm purposefulness of the described supplementation of food rations, especially in the situation of common use of TMR system on highly efficient cow farms.

Fish oil applied to cow food provides good source of the acids from n-3 group (EPA and DHA). As it has been proved in our own investigation, the use of this acids is connected with significant increase in EPA and DHA concentration in cow milk fat. Also administration of fish oil and soy oil resulted in the increase in concentration of fatty acids from n-3 (EPA and DHA) group ${ }^{[1]}$. That fact was also confirmed by other investigations ${ }^{[2,3,36]}$ which proved that EPA and DHA concentration in cow milk fat did considerably increase after application of vegetable oils with fish oil. Generally, EPA and DHA transfer from food ration to milk is low ${ }^{[1]}$ since they are preferentially deposited in body tissues rather than in milk fat. The results obtained confirm purposefulness of fish oil supplementation in cow food rations which is also reflected in milk nutritional value in human diet.

Summing up it is possible to state that administration of fish oil in the form of F-M preparation amounting $1 \%$ of oil in $1 \mathrm{~kg}$ of TMR dry mass food ration advantageously affected alteration of fatty acid profile in milk fat. There was recorded decreased level of short chain fatty acids, while the one of long chain acids increased. Cis-9, trans-11 CLA isomer concentration considerably increased, as well as that of polyunsaturated fatty acids of n-3 group, EPA and DHA. The ratio n-6/n-3 underwent noticeably lowering as early as 4 weeks of preparation administration. 
Am. J. Agril. \& Biol. Sci., 2 (4): 276-283, 2007

Table 1: Content and nutritional composition of the cows diets

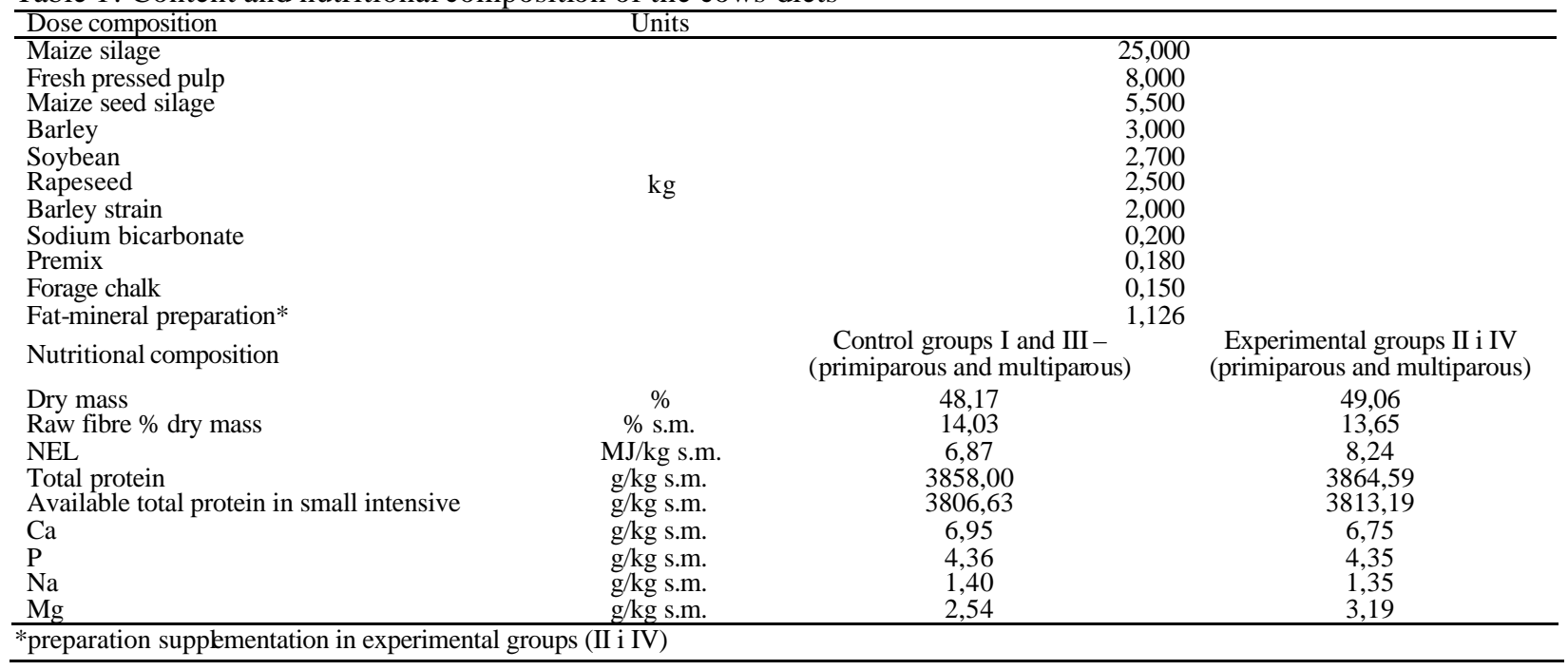

Table 2: The scheme of the experiment

\begin{tabular}{ccccc}
\hline Cows & I - control & II - experimental & III - control & IV - experimental \\
\hline Primiparous & No supplement & $\begin{array}{c}\text { supplement }- \text { fish oil } \\
(1 \% \text { of dry DM })\end{array}$ & - & - \\
Multiparous & - & - & No supplement & supplement - fish oil \\
$(1 \%$ of DM $)$ & \\
\hline
\end{tabular}

Table 3: Fatty acids composition in fish oil

\begin{tabular}{|c|c|c|c|}
\hline Fatty acid & & Chemical formula & Average content $(\%)$ \\
\hline Myristic acid & \multirow[b]{7}{*}{ S SFAs } & $\mathrm{C}_{14: 0}$ & 5,97 \\
\hline Pentadecanoic acid & & $\mathrm{C}_{15: 0}^{140}$ & 0,62 \\
\hline Palmitic acid & & $\mathrm{C}_{16: 0}$ & 15,69 \\
\hline Stearic acid & & $\mathrm{C}_{18: 0}$ & 2,85 \\
\hline Arachidic acid & & $\mathrm{C}_{20: 0}$ & 0,19 \\
\hline \multirow[t]{2}{*}{ Behenic acid } & & $\mathrm{C}_{22: 0}$ & 0,90 \\
\hline & & & 26,22 \\
\hline Myrisoleic acid & \multirow[b]{8}{*}{ S MUFAs } & $\mathrm{C}_{14: 1 \mathrm{n}-7}$ & 0,43 \\
\hline Palmitoleic acid & & $C_{16: 1} \mathrm{n}-7$ & 3,52 \\
\hline Heptadecanoic acid & & $\mathrm{C}_{17: 1 \mathrm{n}-7}$ & 0,45 \\
\hline Oleinic acid & & $C_{18: 1} \mathrm{n}-9 \mathrm{c}$ & 22,86 \\
\hline Gadoleic acid & & $\mathrm{C}_{20: 1} \mathrm{n}-9$ & 2,94 \\
\hline Erucic acid & & $C_{22: 1} n-9 c$ & 4,17 \\
\hline Tetracosenoic acid & & $\mathrm{C}_{24: 1}$ & 1,015 \\
\hline \multirow{4}{*}{$\begin{array}{l}\text { Linoleic acid (LA) } \\
\alpha \text {-linolenic acid (ALNA) } \\
\gamma \text {-linolenic acid (GLA) }\end{array}$} & & & 35,39 \\
\hline & & $C_{18: 2} n-6 c$ & 7,28 \\
\hline & & $C_{18: 3 n-3 ~ c}$ & 3,84 \\
\hline & & $\mathrm{C}_{18: 3 \mathrm{n}-6}$ & 0,11 \\
\hline Stearidonic acid & & $\mathrm{C}_{18: 4} \mathrm{n}-3$ & 1,82 \\
\hline Eicozadienoic acid & & $\mathrm{C}_{20: 2 \mathrm{n}-6}$ & 1,76 \\
\hline Eicozatrienoic acid & & $\mathrm{C}_{20: 3 \mathrm{n}-3}$ & 0,20 \\
\hline Arachidonic acid (AA) & & $C_{20: 4} n-6$ & 0,92 \\
\hline Eicosapentaenoic (EPA) acid & & $C_{20: 5} \mathrm{n}-3$ & 8,19 \\
\hline Docosatetraenoic acid & & $\mathrm{C}_{22: 4} \mathrm{n}-6$ & 0,76 \\
\hline Docosapentaenoic acid (DPA) & & $\mathrm{C}_{22: 5} \mathrm{n}-3$ & 1,62 \\
\hline \multirow[t]{6}{*}{ Docohexaenoic acid (DHA) } & & $C_{22: 6} n-3$ & 13,83 \\
\hline & S PUFAs & & 40,43 \\
\hline & S L-PUFAs & & 23,64 \\
\hline & $n-3$ family acids & & 29,50 \\
\hline & n-6 family acids & & 10,83 \\
\hline & $n-6 / n-3$ & & 0,37 \\
\hline
\end{tabular}

SFAs - saturated fatty acids, MUFAs - monounsaturated fatty acids, PUFAs - polyunsaturated fatty acids, L-PUFAs - long-chain polyunsaturated fatty acids (total EPA, DPA, DHA), EPA - eicosapentaenoic acid; DPA docosapentaenoic acid, DHA - docohexaenoic acid 
Am. J. Agril. \& Biol. Sci., 2 (4): 276-283, 2007

Table 4: Fatty acids composition in milk fatof cows - primiparous (g/100g fatty acids)

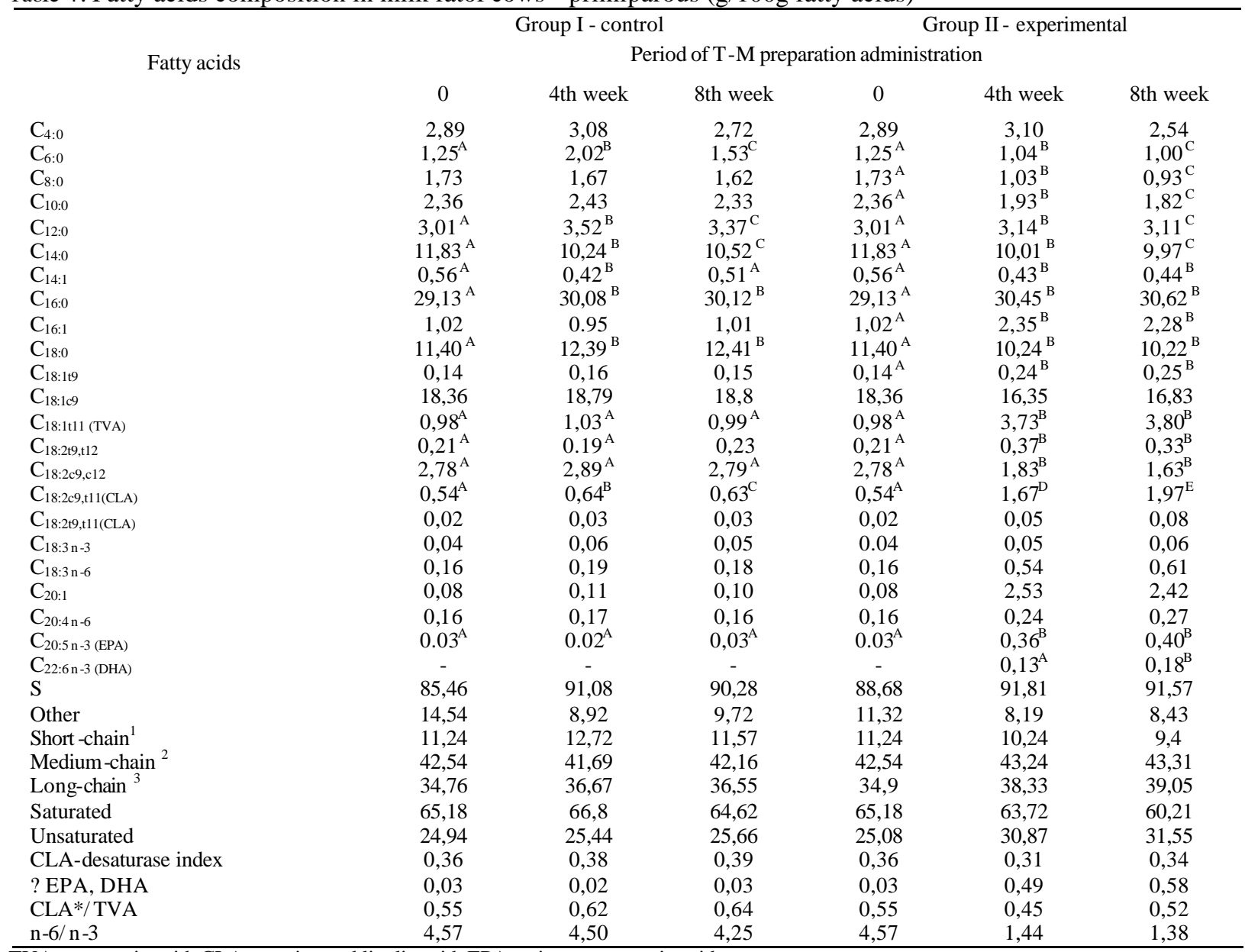

TVA - vaccenic acid, CLA - coniugated linolic acid, EPA - eicosapentaenoic acid,

DHA - docohexaenoic acid

${ }^{1}$ - short -chain fatty acids (C4:0 - C12:0); ${ }^{2}$ - medium-chain fatty acids (C14:0 - C16:1);

3 - ling-chain fatty acids (> C16:0)

* $\mathrm{C}_{18: 2 \mathrm{2c}, \mathrm{t11}}$ CLA

A,B,C - refer to significant differences $(\mathrm{p}<0.01)$

Table 5: Fatty acids composition in cow milk fat - multiparous (g/100g fatty acids)

\begin{tabular}{|c|c|c|c|c|c|c|}
\hline \multirow{3}{*}{ Fatty acids } & \multicolumn{3}{|c|}{ Group III - control } & \multicolumn{3}{|c|}{ Group IV - experimental } \\
\hline & \multicolumn{6}{|c|}{ Period of T-M preparation administration } \\
\hline & 0 & 4th week & 8th week & 0 & 4th week & 8th week \\
\hline $\mathrm{C}_{4: 0}$ & $3,14^{\mathrm{A}}$ & $3,89^{\mathrm{A}}$ & $3,25^{\mathrm{A}}$ & $3,14^{\mathrm{A}}$ & $2,34^{\mathrm{B}}$ & $1,99^{\mathrm{B}}$ \\
\hline $\mathrm{C}_{6: 0}$ & $2,34^{\mathrm{A}}$ & $2,45^{\mathrm{B}}$ & $2,31^{\mathrm{C}}$ & $2,34^{\mathrm{A}}$ & $2,01^{\mathrm{B}}$ & $1,82^{\mathrm{C}}$ \\
\hline $\mathrm{C}_{8: 0}$ & $1,82^{\mathrm{A}}$ & $2,06^{\mathrm{B}}$ & $1,73^{\mathrm{A}}$ & $1,82^{\mathrm{A}}$ & $1,89^{\mathrm{A}}$ & $1,31^{\mathrm{B}}$ \\
\hline $\mathrm{C}_{10: 0}$ & $2,84^{\mathrm{A}}$ & $2,73^{\mathrm{B}}$ & $2,62^{\mathrm{C}}$ & $2,84^{\mathrm{A}}$ & $2,21^{\mathrm{B}}$ & $2,01^{\mathrm{C}}$ \\
\hline $\mathrm{C}_{12: 0}$ & 3,56 & 3,63 & 3,41 & $3,56^{\mathrm{A}}$ & $3,61^{\mathrm{B}}$ & $3,54^{\mathrm{A}}$ \\
\hline $\mathrm{C}_{14: 0}$ & $11,93^{\mathrm{A}}$ & $10,43^{\mathrm{B}}$ & $10,58^{\mathrm{B}}$ & $11,93^{\mathrm{A}}$ & $10,24^{\mathrm{B}}$ & $10,21^{\mathrm{B}}$ \\
\hline $\mathrm{C}_{14: 1}$ & $0,62^{\mathrm{A}}$ & $0,52^{\mathrm{B}}$ & $0,59^{\mathrm{C}}$ & $0,62^{\mathrm{A}}$ & $0,53^{\mathrm{B}}$ & $0,47^{\mathrm{C}}$ \\
\hline$C_{16: 0}$ & 30,24 & 30,11 & 30,50 & 30,24 & 30,24 & 31,02 \\
\hline $\mathrm{C}_{16: 1}$ & $1,24^{\mathrm{A}}$ & $1,02^{\mathrm{B}}$ & $1,04^{\mathrm{B}}$ & $1,24^{\mathrm{A}}$ & $2,86^{\mathrm{B}}$ & $2,99^{\mathrm{B}}$ \\
\hline $\mathrm{C}_{18: 0}$ & 12,03 & 12,31 & 12,56 & $12,03^{\mathrm{A}}$ & $10,45^{\mathrm{B}}$ & $11,03^{\mathrm{C}}$ \\
\hline $\mathrm{C}_{18: 119}$ & 0,23 & 0,21 & 0,20 & $0,23^{\mathrm{A}}$ & $0,35^{\mathrm{B}}$ & $0,34^{\mathrm{B}}$ \\
\hline $\mathrm{C}_{18: \mathrm{lc} 9}$ & 17,45 & 18,20 & 18,36 & 17,45 & 16,24 & 16,01 \\
\hline $\mathrm{C}_{18: 1 \mathrm{lt1}(\mathrm{TVA})}$ & $1,45^{\mathrm{A}}$ & $1,04^{\mathrm{A}}$ & $1,12^{\mathrm{A}}$ & $1,45^{\mathrm{A}}$ & $4,12^{\mathrm{B}}$ & $3,71^{\mathrm{B}}$ \\
\hline
\end{tabular}


Am. J. Agril. \& Biol. Sci., 2 (4): 276-283, 2007

\begin{tabular}{|c|c|c|c|c|c|c|}
\hline $\mathrm{C}_{18: 2 \mathrm{t} 9, \mathrm{t} 12}$ & $0,17^{\mathrm{A}}$ & $0,15^{\mathrm{A}}$ & $0,15^{A}$ & $0,17^{\mathrm{A}}$ & $0,42^{\mathrm{B}}$ & $0,40^{\mathrm{B}}$ \\
\hline $\mathrm{C}_{18: 2 \mathrm{c} 9, \mathrm{c} 12}$ & $3,11^{\mathrm{A}}$ & $3,02^{\mathrm{A}}$ & $3,09^{\mathrm{A}}$ & $3,11^{\mathrm{A}}$ & $1,93^{\mathrm{B}}$ & $1,89^{\mathrm{B}}$ \\
\hline $\mathrm{C}_{18: 2 \mathrm{c} 9, \mathrm{t} 11 \text { (CLA) }}$ & $0,62^{\mathrm{A}}$ & $0,64^{\mathrm{A}}$ & $0,60^{\mathrm{A}}$ & $0,62^{\mathrm{A}}$ & $2,75^{\mathrm{B}}$ & $2,82^{\mathrm{C}}$ \\
\hline $\mathrm{C}_{18: 2 t 9, \mathrm{t} 11 \text { (CLA) }}$ & $0,05^{\mathrm{A}}$ & $0,05^{\mathrm{A}}$ & $0,06^{\mathrm{A}}$ & $0,05^{\mathrm{A}}$ & $0,15^{\mathrm{B}}$ & $0,18^{\mathrm{C}}$ \\
\hline $\mathrm{C}_{18: 3 n-3}$ & 0,03 & 0,04 & 0,09 & $0.03^{\mathrm{A}}$ & $0,10^{\mathrm{B}}$ & $0,20^{\mathrm{C}}$ \\
\hline $\mathrm{C}_{18: 3 n-6}$ & 0,17 & 0,20 & 0,22 & 0,17 & 0,72 & 0,80 \\
\hline $\mathrm{C}_{20: 1}$ & 0,07 & 0,14 & 0,15 & 0,07 & 3,01 & 2,95 \\
\hline $\mathrm{C}_{20: 4 n-6}$ & 0,18 & 0,20 & 0,19 & 0,18 & 0,28 & 0,31 \\
\hline $\mathrm{C}_{20: 5 n-3}$ (EPA) & $0.02^{\mathrm{A}}$ & $0,03^{\mathrm{A}}$ & $0,02^{\mathrm{A}}$ & $0.02^{\mathrm{A}}$ & $0,46^{\mathrm{B}}$ & $0,46^{\mathrm{B}}$ \\
\hline $\mathrm{C}_{22: 6 \mathrm{n}-3 \text { (DHA) }}$ & - & - & - & - & $0,25^{\mathrm{A}}$ & $0,31^{\mathrm{B}}$ \\
\hline $\mathrm{S}$ & 93,31 & 93,07 & 90,02 & 93,31 & 97,16 & 96,77 \\
\hline inne & 6,69 & 6,93 & 9,98 & 6,69 & 2,84 & 3,23 \\
\hline Short-chain ${ }^{1}$ & 13,7 & 14,76 & 10,07 & 13,7 & 12,06 & 10,67 \\
\hline Medium-chain ${ }^{2}$ & 44,03 & 42,08 & 42,71 & 44,03 & 43,87 & 44,69 \\
\hline Long-chain ${ }^{3}$ & 35,58 & 36,23 & 36,61 & 35,58 & 41,23 & 41,41 \\
\hline Saturated & 69,76 & 67,15 & 65,97 & 69,76 & 66,38 & 62,93 \\
\hline Unsaturated & 25,41 & 25,46 & 24,05 & 25,41 & 34,17 & 33,84 \\
\hline CLA-desaturase index & 0,30 & 0,38 & 0,35 & 0,30 & 0,40 & 0,43 \\
\hline$?$ EPA, DHA & 0,02 & 0,03 & 0,02 & 0,02 & 0,71 & 0,77 \\
\hline CLA*/TVA & 0,43 & 0,62 & 0,54 & 0,43 & 0,67 & 0,76 \\
\hline$n-6 / n-3$ & 7,00 & 5,71 & 3,73 & 7,00 & 1,23 & 1,14 \\
\hline
\end{tabular}

TVA - vaccenic acid, CLA - coniugated linolic acid, EPA - eicosapentaenoic acid,

DHA - docohexaenoic acid

${ }^{1}$ - short -chain fatty acids (C4:0 - C12:0) ${ }^{2}$ - medium-chain fatty acids (C14:0 - C16:1);

3 - long-chain fatty acids (> C16:0)

* $\mathrm{C}_{18: 2 \mathrm{c} 9, \mathrm{t} 11}$ CLA

A,B,C - refer to significant differences $(\mathrm{p}<0.01)$

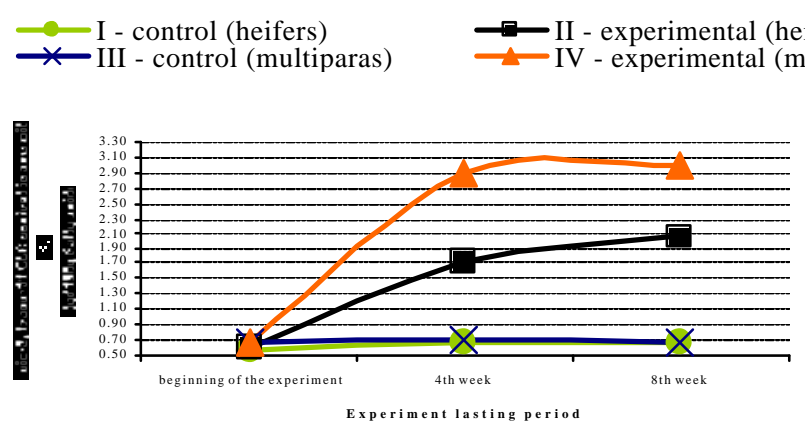

Fig. 1: CLA content in cow milk fat [g/100 g fatty acids]

\section{ACKNOWLEDGMENTS}

The research was granted by Polish Ministry of Science and Higher Education, grant No. 2 P06Z 06027.

\section{REFERENCES}

1. AbuGhazaleh A.A., Schingoethe D.J., Hippen A.R., Kalscheur K.F., 2004. Conjugated linoleic acid increases in milk when cows fed fish meal and extruded soybeans for an extended period of time. J. Dairy Sci. 87: 1758-1766.

2. Abu-Ghazaleh A.A., Schingoethe D.J., Hippen A.R., Kalscheur K.F., 2003: Milk conjugated linoleic acid response to fish supplementation of diets differing in fatty acid profiles. J. Dairy Sci. 86 (3): 944-953.
3. Abu-Ghazaleh A.A., Schingoethe D.J., Hippen A.R., Whitlock L.A., 2002. Feeding fish meal and extruded soybeans enhances the conjugated linoleic acid (CLA) content of milk. J. Dairy Sci. 85 (3): 624-631.

4. AOAC. 2000. Official methods of analysis of the association on official analytical chemists. ${ }^{17 \text { th }} \mathrm{Ed}$. Kenneth Helrich, Arlington, USA.

5. Bakula T., Apoznanski J., Obremski K., Iwaniuk Z., Gajecki M., 2005. Sklad chemiczny wybranych rybnych materialów paszowych. Medycyna Wet. 61 (9): 1061-1063.

6. Bauman D. E., Baumgard L. H., Corl B. A., Griinari J. M. 2000. Biosynthesis of conjugated linoleic acid in ruminants. Proc. Am. Soc. Anim. Sci. Available at: www.asas.org/jas/symposia/proceedings/0937.pdf.

7. Bauman D. E., Corl B. A., Peterson D. G., 2003. The biology of conjugated linoleic acids in ruminants. Pages 146-173. Advances in Conjugated Linoleic Acid Research, Vol. 2. Sebedio J.L., Christie W. W., Adlof R. OAOCS Press, Champaign, IL.

8. Chilliard Y., Ferlay A., Doreau M., 2001. Effect of different types of forages, animal fat or marine oils in cow's diet on milk fat secretion and composition, especially conjugated linoleic acid (CLA) and polyunsaturated fatty acids. Livest. Prod. Sci. 70: 31-48.

9. Chouinard P. Y., Corneau L., Butler W. R., Chilliard Y., Drackley J. K., Bauman D. E., 2001. Effect of dietary lipid source on conjugated linoleic acid concentrations in milk fat. J. Dairy Sci. 84: 680-690. 
10. Corl B.A., Baumgard L.H., Dwyer D.A., Griinari J.M., Phillips B.S., Bauman D.E., 2001. The role of .9-desaturase in the production of cis-9, trans-11 CLA. J. Nutr. Biochem. 12: 622-630.

11. Corl B.A., Baumgard L.H., Griinari J.M., Delmonte P., Morehouse K.M., Yurawecz M., Bauman D.E., 2002. Trans-7, cis-9 CLA is synthesized endogenously by .9-desaturase in dairy cows. Lipids. 37: 681-688.

12. Dhiman T.R, Satter L.D, Pariza M.W, Galli M.P, Albright K., Tolosa M.X., 2000. Conjugated linoleic acid (CLA) content of milk from cows offered diets rich in linoleic and linolenic acid. $\mathbf{J}$ Dairy Sci. 83 (5): 1016-1027.

13. DLG - Tabele wartosci pokarmowej pasz i norm zywienia przezuwaczy. Wyd. II uzupelnione, PPH VIT-TRA, Kusowo. 2001.

14. Donovan D.C., Schingoethe D.J., Baer R.J., Ryali J., Hippen A.R., Franklin S.T., 2000: Influence of dietary fish oil on conjugated linoleic acid and other fatty acids in milk fat from lactating dairy cows. J. Dairy Sci. 83 (11): 2620-2628.

15. Elizalde J. C., Aldrich C. G., LaCount D. W., Druckley J. K., Marchen N. R. (1999) Ruminal and total tract digestibilitis in steers fed diets containing liguefied or prilled saturated fatty acids. J. Anim. Sci. 77, 1930-1939.

16. Espindola M S., De Peters E. J. Fadel J. G., Zinn R. A., Perez-Monti H. (1997) Effect on nutrient degistion of wheat procesing and method of tallow addition to the diets of lactating dairy cows. J. Dairy Sci. 80, 1160-1171.

17. Griinari J.M., Corl B.A., Lacy S.H., Chouinard P.Y., Nurmela K.V., Bauman D.E., 2000. Conjugated linoleic acid is synthesized endogenously in lactating dairy cows by delta.9desaturase. J. Nutr. 130: 2285-2291.

18. Jenknis T. C. (2000) Feeding oleamide to lactating jersey cows. I Effects on lactation performance and milk fatty acid composition. J. Dairy Sci. 83, 332337.

19. Kay J.K., Mackle T.R., Auldist M.J., Thomsan N.A., Bauman D.E., 2004. Endogenous synthesis of cis-9, trans-11 conjugated linoleic acid in dairy cows fed fresh pasture. J. Dairy Sci. 87: 369-378.

20. Kelly, M.L., J.R. Berry, D.A. Dwyer, J.M. Griinari, P.Y. Chouinard, M.E. Van Amburgh and D.E. Bauman, 1998. Dietary fatty acid sources affect conjugated linoleic acid concentrations in milk from lactating airy cows. J. Nutr. 128: 881-885.

21. Kelsey J.A., Corl B.A., Collier R.J., Bauman D.E., 2003. The effect of breed, parity, and stage of lactation on conjugated linoleic acid (CLA) in milk fat from dairy cows. J. Dairy Sci. 86 (8): 25882597.

22. Kritchevsky D., 2000. Antimutagenic and some other effects of conjugated linoleic acid. Br. J. Nutr. 83 (5): 459-465.

23. Lawless F., Murphy J.J., Harrington D., Devery R., Stanton C., 1998. Elevation of cis-9, trans-11octadecadienoic acid in bovine milk because of dietary supplementation. J. Dairy Sci. 81: 32593267.
24. Loor, J.J., Ferlay A., Ollier A., Ueda K., Doreau M., Chilliard Y., 2005. High-concentrate diets and polyunsaturated oils alter trans and conjugated isomers in bovine rumen, blood, and milk. J. Dairy Sci. 88: 3986-3999.

25. Nowak W., Potkanski A., 2000. The effect of rolled rapseed on milk composition and lactational responses. J. Anim. Feed. Sci. 9, 425-434.

26. Offer, N.W., Marsden M., Dixon J., Speake B.K., Thacker F.E., 1999. Effect of dietary fat supplements on levels of $n-3$ poly -unsaturated fatty acids, trans acids and conjugated linoleic acid in bovine milk. Anim. Sci. 69: 613-625.

27. Peterson D.G., Kelsey J.A., Bauman D.E., 2002. Analysis of variation in cis-9, trans-11 conjugated linoleic acid (CLA) in milk fat of dairy cows. J. Dairy Sci. 85: 2164-2172.

28. Piperova, L.S., Sampugna J., Teter B.B., Kalscheur K.F., Yurawecz M.P., Ku Y., Morehouse K.M., Erdman R.A., 2002. Duodenal and milk trans octadecenoic acid and conjugated linoleic acid (CLA) isomers indicate thatpostabsorptive synthesis is the predominant source of cis-9containing CLA in lactating dairy cows. J. Nutr.132: 1235-1241.

29. Pires A. V., Eastridge M. L., Firkins J. L., Lin Y. C. 1997. Effects on heat treatment and physical procesing of cottonseed on nutrient digestibility and production performance by lactating cows. J. Dairy Sci. 80, 1685-1694.

30. PN-EN ISO 5508, 1996

31. Ritzenthaler K.L., McGuire M.K., Falen R., Shultz T.D., Dasgupta N., McGuire M.A., 2001. Estimation of conjugated linoleic acid intake by written dietary assessment methodologies underestimates actual intake evaluated by food duplicate methodology. J. Nutr. 131: 1548-1554.

32. Roche H.M., Noone E., Nugent A., Gibney M.J., 2001. Conjugated linoleic acid: a novel therapeutic nutrient? Nutr. Res. Rev. 14: 173-187.

33. Shingfield K., Ahvenjärvi S., Toivonen V., Ärölä A., Nurmela K.V.V., Huhtanen P., Griinari J. 2003. Effect of dietary fish assn an ODs oil on biohydrogenation of fatty acids and milk fatty acid content in cows. Anim. Sci 77: 165-179.

34. Shingfield K.J. Reynolds C.K., Hervas G., Griinari J.M., Grandison A.S., Beever D.E., 2006. Examination of the persistency of milk fatty acid composition responses to fish oil and sunflower oil in the diet of dairy cows. J. Dairy Sci. 89: 714-732.

35. Whitlock L., Schingoethe D.J., Hippen A.R., Kalscheur K.F., Baer R.J., Ramaswamy N., Kasperson K.M., 2002. Fish oil and extruded soybeans fed in combination increase CLA in milk of dairy cows more than when fed separately. J. Dairy Sci. 85: 234-243.

36. Whitlock L.A., Schingoethe D.J., Hippen A.R., Kalscheur K.F., Abu-Ghazaleh A.A., 2003. Milk production and composition from cows fed high oil or conventional corn at two forage concentrations. J. Dairy Sci. 86: 2428-2437. 